\title{
Effect of a bacterial inoculant on rate of fermentation and chemical composition of high dry matter grass silages
}

\author{
F. DRIEHUIS, P. G. VAN WIKSELAAR, A. M. van VUUREN AND S. F. SPOELSTRA \\ DLO-Institute for Animal Science and Health (ID-DLO), Department of Ruminant Nutrition, PO Box 65 , \\ 8200 AB Lelystad, The Netherlands
}

(Revised MS received 28 June 1996)

\begin{abstract}
SUMMARY
Four experiments were carried out in Lelystad, The Netherlands in 1994, in which perennial ryegrass wilted to $421-568 \mathrm{~g}$ dry matter (DM) $\mathrm{kg}^{-1}$ was ensiled with and without an inoculant containing Lactobacillus plantarum and Enterococcus faecium strains in 1-litre capacity laboratory silos. Treated silages showed a markedly increased rate of $\mathrm{pH}$ decline. The final $\mathrm{pH}$ of treated silages was reached 20-30 days after ensiling, whereas acidification of control silages continued during the full 180-day ensilage period. After 180 days ensilage, treated silages showed significantly $(P<0 \cdot 001)$ lower $\mathrm{pH}$, $\mathrm{DM}$ loss and ammonia-N concentrations and significantly $(P<0.001)$ higher lactic acid concentrations than control silages in all experiments. Concentrations of ethanol and acetic acid were significantly (at least $P<0 \cdot 05$ ) lower for the treated silages, except for acetic acid in one experiment and ethanol in another. Butyric acid was not found in any of the silages. One of the control silages (ensiled at $517 \mathrm{~g} \mathrm{DM} \mathrm{kg}^{-1}$ ) contained ethanol as the major fermentation product indicating that alcoholic fermentation had taken place, probably by yeasts. Treated and untreated grasses used in the first experiment (432 and $442 \mathrm{~g} \mathrm{DM} \mathrm{kg}^{-1}$, respectively) were also used to produce silages in two 40-t capacity clamp silos. Similar to the laboratory silos, the treated silage had a higher lactic acid concentration and lower $\mathrm{pH}$ and ethanol, acetic acid and ammonia- $\mathrm{N}$ concentrations than the untreated silage.
\end{abstract}

\section{INTRODUCTION}

Inoculants containing lactic acid bacteria (LAB) can improve the fermentation quality and reduce dry matter (DM) losses of grass silages, providing that the herbage contains sufficient fermentable carbohydrates and the inoculant bacteria dominate the epiphytic population of LAB (Lindgren \& Petterson 1990; Spoelstra 1991). In addition, many studies have shown beneficial effects of inoculant treatment of grass of low and intermediate DM content $\left(<400 \mathrm{~g} \mathrm{~kg}^{-1}\right)$ on silage intake, digestibility and animal performance, and also when the untreated control silages were well preserved (Hooper 1987; Gordon 1989; Potthast \& Kleinmans 1991; Vaitiekunas 1992; Keady \& Steen 1994), although the effects have not been found consistently (Spoelstra 1991).

Increasing the DM content by wilting has proved to be an effective alternative to additive use (Zimmer \& Wilkins 1984; Spoelstra 1990). In regions where production of high DM grass silages prevails, the use of additives is generally restricted to conditions when the desired DM content is not reached within 2 or 3 days of wilting (Wilkinson \& Stark 1992). This probably also explains why the effects of inoculants on high DM grass silages have received so little attention in the literature. The present study investigates the influence of an inoculant containing Lactobacillus plantarum and Enterococcus faecium on the fermentation rate and chemical composition of silages produced from wilted grass of high DM content (400-600 g kg-1).

\section{MATERIALS AND METHODS}

Grass (mainly Lolium perenne) from permanent pastures at Lelystad, fertilized with $300 \mathrm{~kg} \mathrm{~N} \mathrm{ha}^{-1}$ per year, were used in the experiments. Second-cut grass was harvested with a yield of $c .4 \mathrm{t} \mathrm{DM} \mathrm{ha}{ }^{-1}$ on 30 May (Expt 1) and 13 June (Expt 2) 1994. Third-cut grass was harvested with a yield of $c .3 \mathrm{t} \mathrm{DM} \mathrm{ha}^{-1}$ on 5 July (Expt 3) and 11 July (Expt 4) 1994. Grass was 
Table 1. Chemical and microbiological composition of the control (C) and inoculant-treated grasses (I) as ensiled

\begin{tabular}{|c|c|c|c|c|c|c|c|c|}
\hline & \multicolumn{2}{|c|}{ Expt 1} & \multicolumn{2}{|c|}{ Expt 2} & \multicolumn{2}{|c|}{ Expt 3} & \multicolumn{2}{|c|}{ Expt 4} \\
\hline & $\mathrm{C}$ & I & $\mathrm{C}$ & I & $\mathrm{C}$ & I & $\mathrm{C}$ & I \\
\hline $\mathrm{DM}\left(\mathrm{g} \mathrm{kg}^{-1}\right)$ & 422 & 432 & 440 & 421 & 542 & 566 & 551 & 568 \\
\hline Lactobacilli (CFU g $\left.{ }^{-1}\right)$ & $<5 \cdot 0 \times 10^{1}$ & $5 \cdot 2 \times 10^{4}$ & $4 \cdot 7 \times 10^{3}$ & $4.5 \times 10^{4}$ & $1.0 \times 10^{4}$ & $4.9 \times 10^{4}$ & $5 \cdot 4 \times 10^{3}$ & $4.9 \times 10^{4}$ \\
\hline Lactic acid bacteria (CFU g $\left.\mathrm{g}^{-1}\right)$ & $5.9 \times 10^{3}$ & $6.8 \times 10^{4}$ & $8.9 \times 10^{3}$ & $6.5 \times 10^{4}$ & $1 \cdot 3 \times 10^{4}$ & $8.9 \times 10^{4}$ & $1 \cdot 2 \times 10^{4}$ & $8.5 \times 10^{4}$ \\
\hline \multicolumn{9}{|l|}{ Composition of DM $\left(\mathrm{g} \mathrm{kg}^{-1}\right)$} \\
\hline Soluble carbohydrates & 150 & 152 & 179 & 178 & 217 & 210 & 161 & 159 \\
\hline Total N & $23 \cdot 0$ & 23.9 & $23 \cdot 1$ & 23.6 & $19 \cdot 7$ & $20 \cdot 4$ & $25 \cdot 6$ & $26 \cdot 0$ \\
\hline Neutral detergent fibre & 472 & 477 & 428 & 437 & 433 & 429 & 476 & 474 \\
\hline Acid detergent fibre & 251 & 253 & 227 & 235 & 222 & 221 & 250 & 250 \\
\hline Lignin & 19 & 23 & 11 & 11 & 16 & 17 & 23 & 24 \\
\hline
\end{tabular}

mown with a disc mower, spread to cover the total harvested area and wilted for 25-29 h. Three times during the wilting period the grass was turned and spread.

In Expt 1, c. 8 ha of grassland was used. Alternate swaths were harvested with two similar forage loading wagons, one for inoculant-treated herbage and one for untreated herbage. The inoculant consisted of four strains of $L$. plantarum and two strains of E. faecium (Pioneer Brand 1188, Pioneer Hi-Bred International) and was applied in liquid form at a rate of 2.2 litres (t grass) $)^{-1}$ by means of an calibrated applicator equipped with two nozzles (Pioneer HiBred International), placed $c .1 \mathrm{~m}$ in front of the pickup reel at a height of $c .0 .5 \mathrm{~m}$. The application rate was intended to provide $10^{5}$ colony forming units (CFU) $\mathrm{g}^{-1}$. Approximately $40 \mathrm{t}$ herbage from both treatments was ensiled during $3 \mathrm{~h}$ in two clamp silos. Two similar shovel loaders were used to consolidate the herbages. Within $2 \mathrm{~h}$ of completion of filling, the clamps were covered with two polythene sheets, weighted with tyres at the top and with a covering of sand round the periphery. During filling, samples of treated and untreated grass were taken from each wagon load, bulked and sampled for chemical and microbiological analysis. After 100 and 180 days, three randomly distributed vertical core samples of silage were taken from both silos, bulked and analysed for $\mathrm{pH}$ and chemical composition.

Samples of untreated grass taken at the time of ensiling were also used for making laboratory scale silages. The grass was sprayed with demineralized water (control silages) or a suspension of the inoculant at a rate of $25 \mathrm{ml} \mathrm{kg}^{-1}$, while mixing in a concrete mixer. The treatment with water was performed first. The treatment with inoculant was intended to provide $10^{5} \mathrm{CFU} \mathrm{g}{ }^{-1}$. Ensiling was in airtight 1-litre capacity glass jars containing $c .400 \mathrm{~g}$ of grass (16 jars per treatment). Jars were stored for 180 days in the dark at room temperature. Two silages per treatment were opened 4, 8, 12, 20, 30, 60, 90 and 180 days after ensiling and analysed for weight loss and $\mathrm{pH}$. Silages opened 90 and 180 days after ensiling were also analysed for their chemical composition.

In Expts 2, 3 and 4, only laboratory scale silages were produced. About $150 \mathrm{~kg}$ of wilted grass (untreated) was harvested with a forage loading wagon and transported to the laboratory. Procedures for treatment of the grass, ensiling and analysis were as described for Expt 1.

Grass samples were analysed for $\mathrm{pH}$, DM, ash, neutral detergent fibre (NDF), acid detergent fibre (ADF), lignin, 40\% ethanol soluble carbohydrates (SC), total $\mathrm{N}$ and the number of LAB and lactobacilli. Silages were analysed for $\mathrm{pH}, \mathrm{DM}, \mathrm{NDF}, \mathrm{SC}$, lactic acid, volatile fatty acids (VFA), alcohols and ammonia. Grass and silage samples were dried at $70{ }^{\circ} \mathrm{C}$ in an oven and ground to pass a $1-\mathrm{mm}$ screen. DM, ash, NDF, ADF, lignin, SC and $\mathrm{N}$ were determined as described by van Vuuren et al. (1993). Estimations of silage DM were corrected for volatilization of volatile components during oven drying according the formula: $\mathrm{DM}=$ measured $\mathrm{DM}+0.9$ (ethanol) + 0.75 (VFA) +0.08 (lactic acid) +0.47 (ammonia) (Beyer et al. 1986). Bacterial counts, $\mathrm{pH}$ and concentrations of lactic acid, VFA, alcohols and ammonia were determined in extracts of samples of grass or silage, prepared as described by Spoelstra (1983). Ammonia was determined by a modified Berthelot method as decribed by Robinson et al. (1986). Lactic acid was determined by gas chromatography as described by Spoelstra (1983). VFA and alcohols were determined by gas chromatography, using Hewlett Packard 5730A equipment, a $25 \mathrm{~m}$ mediumbore capillary column (Chrompack CP-Sil-5CB) and helium as carrier gas. Lactobacilli and LAB were enumerated on double layered pour plates of Rogosa SL Agar (Difco) pH 5.4 and Rogosa SL Agar pH 6.2 containing $100 \mathrm{mg}^{-1}$ cycloheximide, respectively, incubated at $30^{\circ} \mathrm{C}$ (Reuter 1985). 

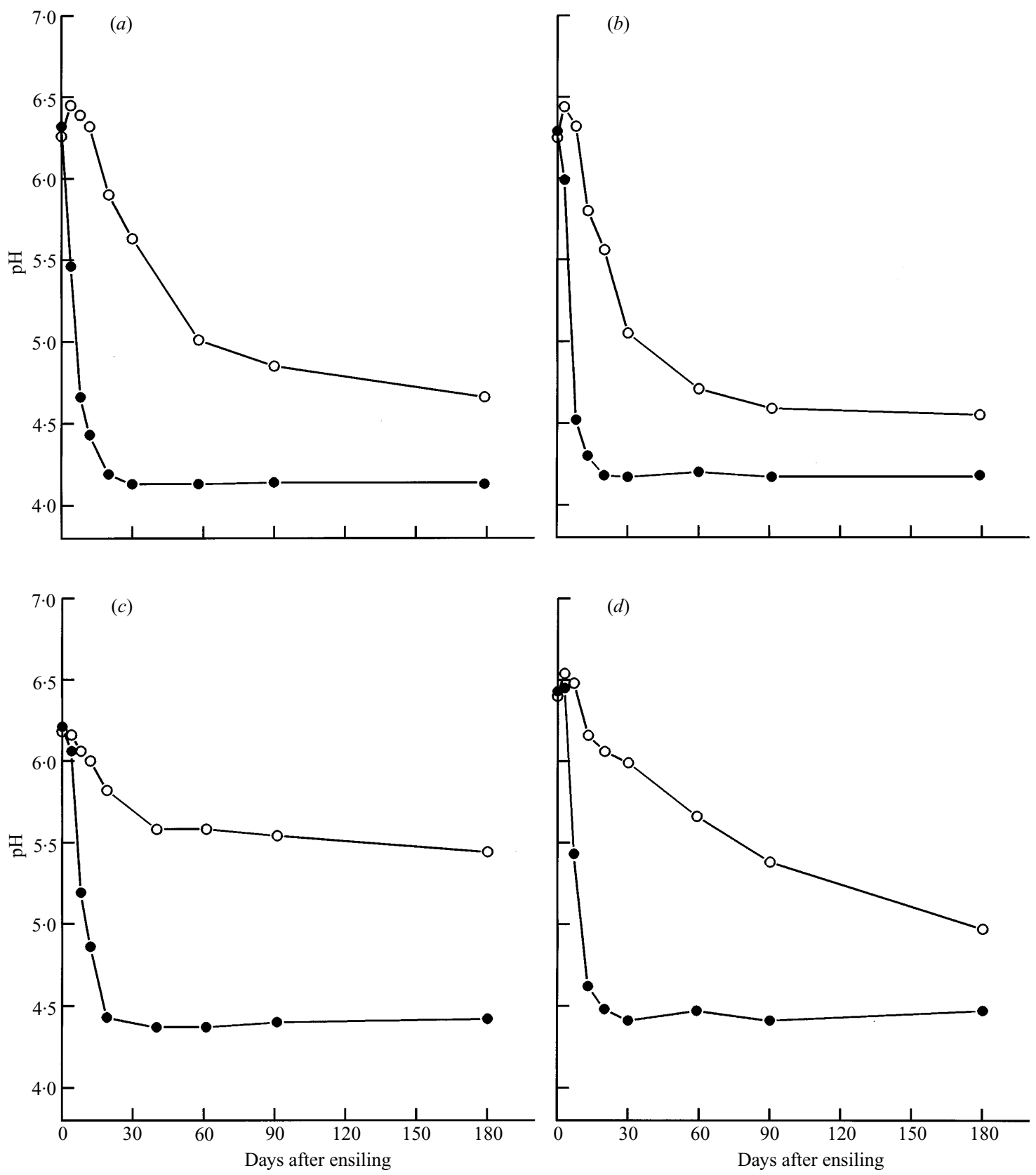

Fig. 1. Silage $\mathrm{pH}$ in the course of ensilage of control $(\bigcirc)$ and inoculant-treated grass $(\bigcirc)$ wilted to $c .430 \mathrm{~g} \mathrm{DM} \mathrm{kg}^{-1}$ in $(a)$ Expt 1 and (b) Expt 2 and to $c .560 \mathrm{~g} \mathrm{DM} \mathrm{kg}^{-1}$ in (c) Expt 3 and (d) Expt 4.

Data for the chemical composition of silages (two replicates) after 90 and 180 days of ensilage were analysed separately by two-way analysis of variance with experiment and inoculation as experimental factors. Differences between treatments were tested using the Student $t$-test.

\section{RESULTS}

The composition of the grasses before ensiling is shown in Table 1. The DM content of the grasses used in Expts 1 and 2 was c. $430 \mathrm{~g} \mathrm{~kg}^{-1}$, that of the grasses used in Expts 3 and 4 was c. $560 \mathrm{~g} \mathrm{~kg}^{-1}$. The 
Table 2. Chemical composition and DM loss during storage of the control $(C)$ and inoculant-treated silages $(I)$ 90 days after ensiling

\begin{tabular}{|c|c|c|c|c|c|c|c|c|c|}
\hline & \multicolumn{2}{|c|}{ Expt 1} & \multicolumn{2}{|c|}{ Expt 2} & \multicolumn{2}{|c|}{ Expt 3} & \multicolumn{2}{|c|}{ Expt 4} & \multirow{2}{*}{$\begin{array}{c}\text { S.E. } \\
\text { (8 D.F.) }\end{array}$} \\
\hline & $\mathrm{C}$ & I & $\mathrm{C}$ & I & $\mathrm{C}$ & I & $\mathrm{C}$ & $\mathrm{I}$ & \\
\hline $\mathrm{DM}\left(\mathrm{g} \mathrm{kg}^{-1}\right)$ & 399 & 419 & 418 & 409 & 528 & 549 & 545 & 548 & $6 \cdot 1$ \\
\hline $\mathrm{DM}$ loss $\left(\mathrm{g} \mathrm{kg}^{-1} \mathrm{DM}\right)$ & $28 \cdot 1$ & $22 \cdot 7$ & 31.9 & $25 \cdot 6$ & $53 \cdot 5$ & $12 \cdot 9$ & $15 \cdot 5$ & $15 \cdot 3$ & 0.97 \\
\hline $\mathrm{pH}$ & $4 \cdot 85$ & $4 \cdot 14$ & $4 \cdot 59$ & $4 \cdot 17$ & $5 \cdot 54$ & $4 \cdot 40$ & $5 \cdot 38$ & $4 \cdot 41$ & $0 \cdot 040$ \\
\hline \multicolumn{10}{|l|}{ Composition of DM $\left(\mathrm{g} \mathrm{kg}^{-1}\right)$} \\
\hline Ash & 114 & 118 & 116 & 113 & 125 & 114 & 91 & 91 & $1 \cdot 4$ \\
\hline Soluble carbohydrates & 105 & 89 & 93 & 94 & 131 & 153 & 140 & 113 & $4 \cdot 7$ \\
\hline Ammonia-N ( $\mathrm{g} \mathrm{kg}^{-1}$ total $\mathrm{N}$ ) & 87 & 58 & 91 & 58 & 53 & 43 & 64 & 48 & $2 \cdot 1$ \\
\hline Ethanol & $13 \cdot 0$ & $8 \cdot 6$ & $13 \cdot 1$ & $9 \cdot 8$ & $39 \cdot 7$ & $5 \cdot 8$ & $7 \cdot 0$ & $4 \cdot 1$ & $0 \cdot 88$ \\
\hline Acetic acid & $9 \cdot 0$ & $7 \cdot 6$ & $19 \cdot 0$ & $10 \cdot 7$ & $4 \cdot 6$ & $6 \cdot 2$ & $7 \cdot 7$ & $6 \cdot 4$ & $0 \cdot 39$ \\
\hline Lactic acid & $35 \cdot 7$ & $64 \cdot 8$ & $49 \cdot 8$ & $69 \cdot 7$ & $7 \cdot 9$ & $40 \cdot 6$ & $15 \cdot 4$ & $43 \cdot 4$ & $4 \cdot 53$ \\
\hline Lactic acid:acetic acid ratio & $4 \cdot 0$ & $8 \cdot 5$ & $2 \cdot 6$ & $6 \cdot 5$ & $1 \cdot 7$ & $6 \cdot 5$ & $2 \cdot 0$ & $6 \cdot 8$ & 0.48 \\
\hline
\end{tabular}

Table 3. Chemical composition and DM loss during storage of the control $(C)$ and inoculant-treated silages $(I)$ 180 days after ensiling

\begin{tabular}{|c|c|c|c|c|c|c|c|c|c|}
\hline & \multicolumn{2}{|c|}{ Expt 1} & \multicolumn{2}{|c|}{ Expt 2} & \multicolumn{2}{|c|}{ Expt 3} & \multicolumn{2}{|c|}{ Expt 4} & \multirow{2}{*}{$\begin{array}{c}\text { S.E. } \\
\text { (8 D.F.) }\end{array}$} \\
\hline & $\mathrm{C}$ & I & $\mathrm{C}$ & I & $\mathrm{C}$ & I & $\mathrm{C}$ & $\mathrm{I}$ & \\
\hline $\mathrm{DM}\left(\mathrm{g} \mathrm{kg}^{-1}\right)$ & 432 & 393 & 423 & 400 & 517 & 540 & 553 & 559 & $6 \cdot 9$ \\
\hline DM loss ( $\left.\mathrm{g} \mathrm{kg}^{-1} \mathrm{DM}\right)$ & $28 \cdot 8$ & $25 \cdot 5$ & $37 \cdot 1$ & $30 \cdot 7$ & $54 \cdot 0$ & $16 \cdot 1$ & $19 \cdot 4$ & $15 \cdot 2$ & $0 \cdot 61$ \\
\hline $\mathrm{pH}$ & $4 \cdot 66$ & $4 \cdot 13$ & $4 \cdot 55$ & $4 \cdot 18$ & $5 \cdot 44$ & $4 \cdot 42$ & $4 \cdot 97$ & $4 \cdot 47$ & $0 \cdot 042$ \\
\hline \multicolumn{10}{|l|}{ Composition of DM ( $\left.\mathrm{g} \mathrm{kg}^{-1}\right)$} \\
\hline Ash & 126 & 118 & 114 & 111 & 128 & 112 & 92 & 92 & $1 \cdot 6$ \\
\hline Soluble carbohydrates & 121 & 111 & 118 & 137 & 152 & 198 & 129 & 127 & $5 \cdot 4$ \\
\hline Neutral detergent fibre & 442 & 461 & 428 & 442 & 423 & 425 & 453 & 464 & $1 \cdot 1$ \\
\hline Ammonia- $\mathrm{N}\left(\mathrm{g} \mathrm{kg}^{-1}\right.$ total $\left.\mathrm{N}\right)$ & 87 & 56 & 94 & 59 & 65 & 45 & 64 & 49 & $1 \cdot 5$ \\
\hline Ethanol & $10 \cdot 0$ & $7 \cdot 7$ & $12 \cdot 9$ & $11 \cdot 9$ & $44 \cdot 9$ & $7 \cdot 3$ & $7 \cdot 1$ & $3 \cdot 9$ & $0 \cdot 48$ \\
\hline Acetic acid & $13 \cdot 2$ & $10 \cdot 0$ & $20 \cdot 7$ & $10 \cdot 3$ & $6 \cdot 0$ & $6 \cdot 6$ & $10 \cdot 8$ & $6 \cdot 3$ & $0 \cdot 73$ \\
\hline Lactic acid & $43 \cdot 3$ & $72 \cdot 3$ & $49 \cdot 7$ & $72 \cdot 1$ & $9 \cdot 9$ & $40 \cdot 2$ & $26 \cdot 0$ & $55 \cdot 3$ & $2 \cdot 52$ \\
\hline Lactic acid:acetic acid ratio & $3 \cdot 3$ & $7 \cdot 2$ & $2 \cdot 4$ & $7 \cdot 0$ & $1 \cdot 6$ & $6 \cdot 1$ & $2 \cdot 4$ & $8 \cdot 8$ & $0 \cdot 20$ \\
\hline
\end{tabular}

concentration of $\mathrm{SC}$ was $>150 \mathrm{~g}(\mathrm{~kg} \mathrm{DM})^{-1}$ in all experiments. The number of LAB in inoculant-treated grasses varied from 6.8 to $8.9 \times 10^{4} \mathrm{CFU} \mathrm{g}^{-1}$, which was 7-11 times higher than in control grasses and close to the intended inoculation of $10^{5} \mathrm{CFU} \mathrm{g}^{-1}$. The number of lactobacilli in treated grass varied from 4.5 to $5 \cdot 2 \times 10^{4} \mathrm{CFU} \mathrm{g}^{-1}$.

Fermentation of laboratory silages was monitored by measuring the silage $\mathrm{pH}$ (Fig. 1). Treated silages showed a much faster rate of $\mathrm{pH}$ decline than control silages. Three weeks after ensiling, the treated silages reached their final $\mathrm{pH}$ value $(4 \cdot 1-4 \cdot 2$ in Expts 1 and 2 and $4 \cdot 4-4 \cdot 5$ in Expts 3 and 4 ), whereas the $\mathrm{pH}$ of control silages was still between $5 \cdot 5$ and $6 \cdot 0$. Acidification of control silages continued for at least 3-6 months, but the $\mathrm{pH}$ remained higher $(0 \cdot 4-1 \cdot 0$ units) than that of treated silages.

The chemical composition of the silages 90 and 180 days after ensiling is given in Tables 2 and 3, respectively. All silages were of good quality, as indicated by the low proportion of ammonia-N and the absence of butyric acid $\left(<0 \cdot 2 \mathrm{~g}(\mathrm{~kg} \mathrm{DM})^{-1}\right)$. Chemical composition of 90-day and 180-day silages showed only minor differences. Concentrations of fermentation products in 180-day silages tended to be higher than in the corresponding 90-day silages. Also SC concentrations were in general slightly higher in the 180-day silages, probably as a result of hydrolysis of hemicelluloses or fructosans during ensiling. After 90 and 180 days of ensilage, treated silages had significantly (at least $P<0.05$ ) higher lactic acid concentrations and lower $(P<0.001) \mathrm{pH}$ values and ammonia- $\mathrm{N}$ concentrations than control silages in all four experiments. Acetic acid concentrations were significantly (at least $P<0.05$ ) lower for treated silages, with the exception of silages of Expt 3 . Ethanol concentrations were significantly (at least $P<0.05)$ lower for treated silages, with the exception 
Table 4. Chemical composition of untreated and inoculant-treated silages made in farm-scale silos of Expt 1, 100 and 180 days after ensiling

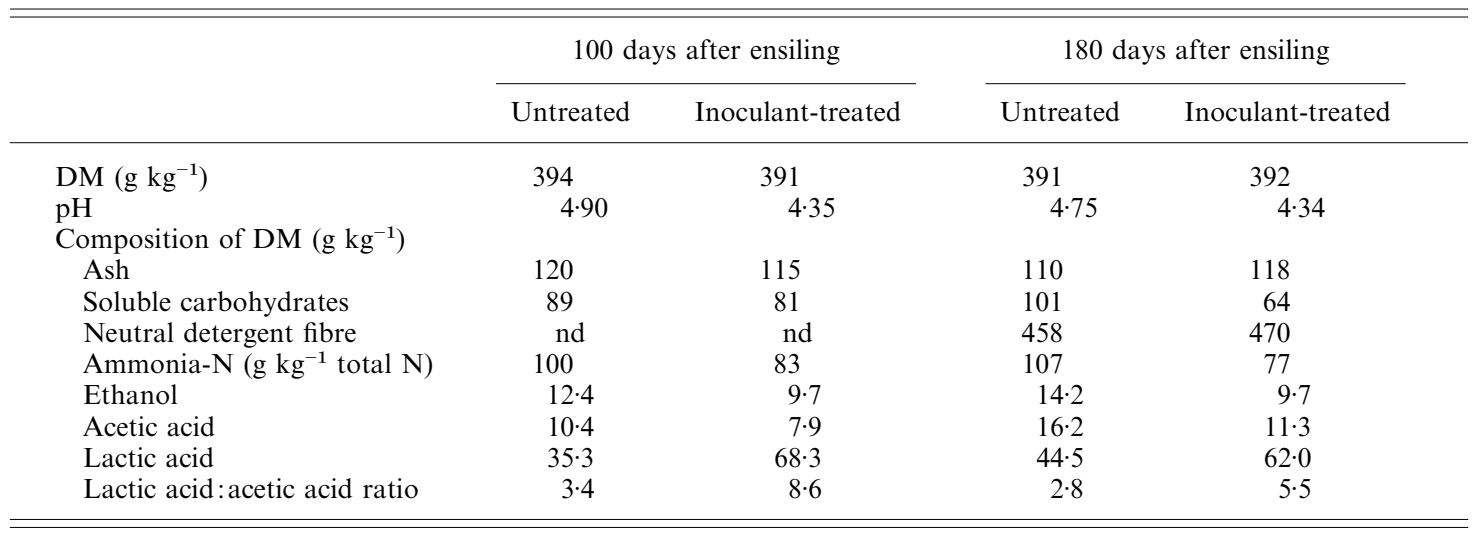

of the 180-day silages of Expt 2. DM loss values were significantly $(P<0 \cdot 001)$ lower for treated silages, with the exception of the 90-day silages of Expt 4. For treated silages the lactic:acetic acid ratio varied from $6 \cdot 1$ to $8 \cdot 8$, whereas for control silages it varied from 1.6 to $4 \cdot 0$. Silages of Expts 1 and 2 (DM content at ensiling $c .430 \mathrm{~g} \mathrm{~kg}^{-1}$ ) showed higher concentrations of lactic acid and ammonia- $\mathrm{N}$ and lower $\mathrm{pH}$ than silages of Expts 3 and 4 (DM content at ensiling $c$. $560 \mathrm{~g} \mathrm{~kg}^{-1}$ ) of the same treatment.

Ethanol was the major fermentation product in the control silage of Expt 3, the molar concentration of ethanol being nine times that of lactic acid (Tables 2 and 3), indicating that an alcoholic rather than a lactic acid fermentation had taken place. A sharp increase in DM loss was detected between 20 and 60 days after ensiling which was not found for the control silages of the other experiments (data not shown), suggesting that the alcoholic fermentation occurred in this period. The responsible microorganisms were not identified. Despite the low acid content, the silage $\mathrm{pH}$ remained stable.

Grass used in Expt 1 was also used to produce inoculant-treated and untreated silages in farm-scale silos. The chemical composition of these silages 90 and 180 days after ensiling showed the same characteristics as did the laboratory silages, i.e. a higher lactic acid concentration, and lower $\mathrm{pH}$, ammonia- $\mathrm{N}$, acetic acid and ethanol concentrations in treated silage than in untreated silage (Table 4). Ammonia-N concentration and $\mathrm{pH}$ of farm-scale silages were slightly higher than in laboratory silages of the same treatment.

\section{DISCUSSION}

Results obtained in the present studies show that treatment with the inoculant substantially increased the rate and extent of fermentation of silages produced from grass wilted to $c .430$ or $c .560 \mathrm{~g} \mathrm{DM} \mathrm{kg}^{-1}$.
Inoculant treatment reduced the lag time before the onset of $\mathrm{pH}$ decline, increased the rate of $\mathrm{pH}$ decline and resulted in a lower final $\mathrm{pH}$ value. These effects have also been reported for grass silages with low or intermediate DM contents (150-400 g DM kg-1) (Honig \& Pahlow 1986; Potthast \& Kleinmans 1991; Keady \& Steen 1994). A comparison of these studies and the present results indicates that the positive effect of inoculant treatment on the rate of fermentation of silages becomes more pronounced with increasing DM content. It is well known that the fermentation rate of silages decreases with increasing DM content, which is explained from the decreasing growth rate of $\mathrm{LAB}$ with decreasing water activity (Lanigan 1963; Greenhill 1964). The differences in the fermentation rate between treated and control silages observed in the present study suggest that the inoculant bacteria possess a high osmotolerance in comparison with the epiphytic flora, giving the inoculant bacteria a growth advantage.

Both for laboratory and farm-scale silages, treatment with the inoculant resulted in significantly higher lactic acid concentrations and lactic:acetic acid ratios, indicating a more homolactic fermentation, and significantly lower ammonia-N proportions and DM losses. Similar effects have been reported for inoculant treatment of grass silages with low and intermediate DM contents (Lindgren \& Petterson 1990; Spoelstra 1991) and lucerne silages (350-550 $\mathrm{g} \mathrm{DM} \mathrm{kg}^{-1}$ ) (Jones et al. 1992).

The DM content of the silages affected the response to the inoculant treatment. The silages produced from grass wilted to $c .430 \mathrm{~g} \mathrm{DM} \mathrm{kg}^{-1}$ (Expts 1 and 2) showed higher lactic acid and ammonia-N concentrations and lower $\mathrm{pH}$ than the silages produced from grass wilted to $c .560 \mathrm{~g} \mathrm{DM} \mathrm{kg}^{-1}$ (Expts 3 and 4). The untreated silages also showed this effect. These observations are in accord with findings of earlier studies showing that the extent of fermentation in 
silages decreases with increasing DM content (Zimmer \& Wilkins 1984; Honig \& Pahlow 1986; Lindgren \& Petterson 1990).

The composition of the control silage in Expt 3 indicates that an alcoholic rather than a lactic acid fermentation occurred (Tables 2 and 3). Yeasts and enterobacteria have been recognised as fermentative micro-organisms other than LAB capable of producing large quantities of ethanol in silage. Fermentation of hexoses by enterobacteria yields, depending on the species, either predominantly ethanol and 2,3-butanediol or a mixture of acids (lactic, acetic, succinic and formic) together with small amounts of ethanol. Fermentation by yeasts yields ethanol as the major fermentation product (McDonald et al. 1991). Since the silage contained no 2,3butanediol $\left(<0 \cdot 1 \mathrm{~g}(\mathrm{~kg} \mathrm{DM})^{-1}\right)$ and a large amount of ethanol relative to lactic and acetic acids, it is likely that yeasts were responsible for the observed ethanol formation. The reason for the predominance of ethanol fermentation in this silage remains unexplained. Grass used in Expt 4 had a similar number of epiphytic LAB and a similar DM content, but in this case no excessive ethanol fermentation was detected in the control silage. The species composition of the epiphytic LAB flora is possibly an important factor.

In conclusion, the results of the present studies, involving both laboratory and farm-scale silages, indicate that treatment with the inoculant improved the fermentation characteristics of high DM grass silages. Whether inoculant treatment of high DM grass silages has beneficial effects on animal performance remains to be investigated.

The authors thank P. G. Hooper and J. Kleinmans (Pioneer Hi-Bred International) for their contribution to the discussions regarding the experimental design and comments on the manuscript. This study was financed by Pioneer Hi-Bred International and the Ministry of Agriculture, Nature Management and Fisheries of The Netherlands and was part of DLO Research Programme 124 (Quality of grass in relation to feed intake and nitrogen utilization).

\section{REFERENCES}

Beyer, M., Chudy, A., Hoffmann, L., Jentsch, W., Laube, W., Nehring, K. \& Schiemann, R. (1986). DDRFutterbewertungssystem. Berlin: VEB Deutscher Landwirtschaftsverlag.

Gordon, F. J. (1989). An evaluation through lactating cattle of a bacterial inoculant as an additive for grass silage. Grass and Forage Science 44, 169-179.

Greenhill, W. L. (1964). Plant juices in relation to silage fermentation. III. Effect of water activity of juice. Journal of the British Grassland Society 19, 336-339.

Honig, H. \& Pahlow, G. (1986). Wirkungsweise und Einsatzgrenzen von Silage-Impfkulturen aus Milchsäurebakterien. 2. Mitteiluung: Wirkung von Anwelgrad, Felddaurer und Zuckerzusatz auf das Konservierungsergebnis bei Gras. Das Wirtschaftseigene Futter 32, 201-228.

HOOPER, P. G. (1987). The effect of an inoculant of lactic acid bacteria on the chemical composition and nutrition value of grass silage. $\mathrm{PhD}$ thesis, University of Newcastle upon Tyne.

Jones, B. A., Satter, L. D. \& Muck R. E. (1992). Influence of bacterial inoculant and substrate addition to lucerne ensiled at different dry matter contents. Grass and Forage Science 47, 19-27.

KeAdy, T. W. J. \& Steen, R. W. J. (1994). Effects of treating low dry-matter grass with a bacterial inoculant on the intake and performance of beef cattle and studies on its mode of action. Grass and Forage Science 49, 438-446.

LANIGAN, G. W. (1963). Silage bacteriology I. Water activity and temperature relationships of silage strains of Lactobacillus plantarum, Lactobacillus brevis and Pediococcus cerevisiae. Australian Journal of Biological Sciences 16, 606-615.

Lindgren, S. \& Petterson, K. L. (Eds) (1990). Proceedings of the Eurobac Conference. Uppsala: Swedish University of Agricultural Sciences.
McDonald, P., Henderson, A. R. \& Heron, S. J. E. (1991). The Biochemistry of Silage (Ed. P. McDonald), pp. 184-236. Marlow: Chalcombe Publications.

Potthast, V. \& Kleinmans, J. (1991). Chemical composition, course of fermentation, in vivo digestibility and in situ measurements in grass silage treated with Pioneer 1188 brand silage inoculant and a control. In Forage Conservation towards 2000, Proceedings European Grassland Federation Conference (Eds G. Pahlow \& H. Honig), Landbauforschung Völkenrode Sonderheft 123, pp. 334337. Braunschweig: Bundesforschungsanstalt für Landwirtschaft Braunschweig-Völkenrode.

Reuter, G. (1985). Elective and selective media for lactic acid bacteria. International Journal of Food Microbiology 2, 55-68.

Robinson, P. H., Tamminga, S. \& van Vuuren, A. M. (1986). Influence of declining level of feed intake and varying the proportion of starch in the concentrate on rumen fermentation in dairy cows. Livestock Production Science 15, 173-189.

SpOELSTRA, S. F. (1983). Inhibition of clostridial growth by nitrate during the early phase of silage fermentation. Journal of the Science of Food and Agriculture 34, 145-152.

Spoelstra, S. F. (1990). Comparison of the content of clostridial spores in wilted grass silage ensiled in either laboratory, pilot-scale or farm silos. Netherlands Journal of Agricultural Science 38, 423-434.

Spoelstra, S. F. (1991). Chemical and biological additives in forage conservation. In Forage Conservation towards 2000, Proceedings European Grassland Federation Conference (Eds G. Pahlow \& H. Honig), Landbauforschung Völkenrode Sonderheft 123, pp. 48-70. Braunschweig: Bundesforschungsanstalt für Landwirtschaft Braunschweig-Völkenrode.

VAITIEKUNAS, W. (1992). Stoffwechselphysiologische Unter- 
suchungen an Milchkühen und Schafen zum Einfluß von Milchsäurebakterien als Siliermittel auf den Futterwert von Gras- und Weizenganzpflanzensilage. $\mathrm{PhD}$ thesis, University of Göttingen.

van Vuuren, A. M., van der Koelen, C. J., Valk, H. \& De VISSER, H. (1993). Effects of partial replacement of ryegrass by low protein feeds on rumen fermentation and nitrogen loss by dairy cows. Journal of Dairy Science 76, 2982-2993.
Wilkinson, J. M. \& Stark, B. A. (1992). Silage in Western Europe, a Survey of 17 Countries. Marlow: Chalcombe Publications.

ZimMER, E. \& WiLKins, R. J. (Eds) (1984). Efficiency of silage systems: a comparison between unwilted and wilted silages, Landbauforschung Völkenrode Sonderheft 69. Braunschweig: Bundesforschungsanstalt für Landwirtschaft Braunschweig-Völkenrode. 